\title{
Effects of Cold and Heat Stress on Egg Quality Traits of a Newly Developed Native Hybrid Layer
}

\author{
Ismail Durmus $^{1 *}$, Serdar Kamanli ${ }^{2}$ \\ ${ }^{1}$ Department of Animal Science, Faculty of Agriculture, Ordu University, 52200 Ordu, Turkey \\ ${ }^{2}$ Poultry Research Station, 06172 Ankara, Turkey
}

\section{A R T I C LE I N F O}

\section{Article history:}

Received 20 February 2015

Accepted 19 March 2015

Available online, ISSN: 2148-127X

\section{Keywords:}

Hen

Cold stress

Heat stress

Egg quality

ATAK-S

\section{A B S T R A C T}

ATAK-S is a newly developed native hybrid layer. Although the laying performance of this hybrid has been studied and determined, the performance response of the hybrid to different environmental temperature conditions is not known. This study was therefore undertaken to determine the effect of cold and heat stress on egg quality traits. Hens were divided into three different groups; control $\left(20^{\circ} \mathrm{C}\right)$, low $\left(12^{\circ} \mathrm{C}\right)$ and high $\left(32^{\circ} \mathrm{C}\right)$. A total of 360 hens, with 120 in each of the groups, were used in the study. Hens were held in three tier battery cages in an environmentally controlled poultry house. The study lasted for 3 weeks. No differences were found among different groups in terms of shape index, albumen height and Haugh unit of the egg quality traits. It was found that the differences among the heat groups in terms of egg shell breaking strength, egg weight, shell thickness and yolk colour were significant and the value of these traits decreased under the heat stress conditions, whereas they were not affected from the cold stress.

\section{Yeni Geliştirilen Yerli Yumurtacı Tavuklarda Soğuk ve Sıcaklık Stresinin Yumurta Kalite Özellikleri Üzerine Etkisi}

\section{A K A L E B İ L G İ S İ}

Geliş 20 Şubat 2015

Kabul 19 Mart 2015

Çevrimiçi baskı, ISSN: 2148-127X

Anahtar Kelimeler:

Tavuk

Soğuk stresi

Sicak stresi

Yumurta kalitesi

ATAK-S

"Sorumlu Yazar:

E-mail: durmusi19@hotmail.com

\section{Ö Z E T}

ATAK-S yeni geliştirilen yerli ticari yumurtacı tavuktur. Bu tavukların verim özellikleri üzerinde araştırmalar yapılmış olmasına rağmen farklı çevre sıcaklıklarına karşı direnci konusunda bilgi bulunmamaktadır. Araştırma, soğuk ve sıcaklık stresinin bu tavuklarda yumurta kalite özellikleri üzerine etkisini belirlemek amacıyla yürütülmüştür. Tavuklar, kontrol $\left(20^{\circ} \mathrm{C}\right)$, düşük $\left(12^{\circ} \mathrm{C}\right)$ ve yüksek $\left(32^{\circ} \mathrm{C}\right)$ sicaklık olmak üzere üç farklı deneme grubuna ayrılmışlardır. Araştırmada her bir grupta 120 adet olmak üzere 360 adet tavuk kullanılmıştır. Tavuklar çevre kontrollü kümeste batarya tipi üç katlı bireysel kafeslerde barındırılmıştır. Stres uygulaması 3 hafta sürdürülmüştür. Araştırmada üzerinde durulan yumurta kalite özelliklerinden şekil indeksi, ak yüksekliği ve haugh birimi bakımından gruplar arasında farklılık bulunmamıştır. Yumurta kabuk kırılma mukavemeti, ağılık, kabuk kalınlığı ve sarı rengi bakımından sıcaklık grupları arasındaki farklılığın önemli olduğu ve yükssek sıcaklık stresinde bu özelliklerin düştüğü tespit edilmiştir. Sonuç olarak, tavuklarda bazı yumurta kalite özellikleri sıcaklık stresi ile düşerken, soğuk stresinden etkilenmemiştir. 


\section{Introduction}

Since mammals and bird species are warm-blooded animals, they have the ability to sustain their body temperature through heat loss or generation. Normally, the body temperature of hens is around $39.4-40^{\circ} \mathrm{C}$. They will not be able to continue their normal performance during changes when there is an increase in body temperature. The thermo neutral zone, which is around $18-23.9^{\circ} \mathrm{C}$ for adult laying hens and $26-27^{\circ} \mathrm{C}$ adult broilers, is crucial for the metabolic and productive activity of hens. Energy is efficiently used for growth, immune system and reproduction activities within thermo neutral zone. On the other hand, hens use a large part of the energy for heat production or loss to control body temperature outside the thermo neutral zone. In such cases, efficiency of feed utilization decreases (Czarick III and Fairchild, 2008).

Heat stress in laying hens has a negative effect on egg efficiency, egg weight and egg quality traits (Daniel and Bolnave, 1979; Ahvar et al., 1982; Deaton, 1983; Gill and Ganwar, 1984; Moshaly et al., 2004; Rozenboim et al., 2007; Feizi et al., 2012). It is reported that there is a difference among lines in terms of tolerating the effect of heat stress and that it is necessary to evaluate the genetic differences with regard to the response against heat stress (Felver et al., 2012).

Many studies have been carried out in order to decrease the effect of heat stress and to prevent the decrease in production traits. Dai et al. (2009) reported that egg production and feed consumption gradually decreased when the drinking water of hens in heat stress was added with $\mathrm{NaCl}$ by 0.2 or $0.4 \%$ during the study. However the production traits returned to normal after the stress period and that the egg production rate decreased in the control group with no supplementation. In another study, it was found that feed efficiency, egg production and Haugh unit values increased by adding vitamin $E$ to the feeds of hens under stress (Ehran and Bolukbasi, 2011). On the other hand, Yardibi and Turkay (2008) pointed out that adding vitamin $\mathrm{E}$ in different dosages to the diet has no positive effect on egg production.

The addition of y-aminobutyric acid (Hui et al., 2010), aspirin (XiaoTing and YouMing, 2002) and betain (Ryu et al., 2002) has been reported to increase or improve albumen height, Haugh unit, egg production, feed efficiency, shell weight and shell thickness or egg shell breaking strength during heat stress period.

ATAK-S is a newly developed commercial layer. It has been developed by crossbreeding of Rhode Island Red and Barred Rock (Durmus et al., 2009). Comparative studies have been undertaken to determine the laying performance of this layer hybrid. Hens of this hybrid reach sexual maturity at an age of 138 days with $1.83 \mathrm{~kg}$ of weight on average. Total egg production for 72 weeks has been determined as 312.8 with an average egg weight of $64.1 \mathrm{~g}$. ATAK-S have a high viability rate, which is about $95.9 \%$. On the other hand, the production response of this hybrid under different temperature and humidity conditions (heat or cold stress) has not been studied. The aim of this study was to investigate the production response of ATAK-S hybrid to heat or cold stress conditions.

\section{Materials and Methods}

Animal material of this study was 360 ATAK-S commercial laying hens located at the Poultry Research Station. Feeds fed to the hens throughout the study were presented with chemical composition in Table 1.

The study was conducted in 3 environmentally controlled poultry houses, each of which is a three tier poultry house that has battery type cage systems with a capacity of 120 hens. The temperature was set automatically to $20 \pm 2{ }^{\circ} \mathrm{C}$ in control group, $12 \pm 2^{\circ} \mathrm{C}$ in low temperature group and $32 \pm 2^{\circ} \mathrm{C}$ in high temperature group. The relative humidity was set at $40 \%$ and ventilation was in a manner to provide $6.5 \mathrm{~m}^{3} /$ hour air circulations per $\mathrm{kg}$ live weight. Chicks were transferred to the poultry house after raising 16 weeks of age in rearing houses to which a $10 \mathrm{~h}$ of environmentally controlled illumination was provided daily. Chicks were randomly distributed to the cage tiers. One pullet was placed to every cage with $29 \times 43 \times 51 \mathrm{~cm}$ dimensions. Illumination period was kept at $10 \mathrm{~h}$ per day until the pullet reached 18 weeks of age; afterwards it was raised by one hour a week and fixed at 16h. Compact fluorescent lamps for illumination were placed with a distance of $120 \mathrm{~cm}$ from the cage on the middle tier in the manner to provide 4 watt $/ \mathrm{m}^{2}$ of light intensity. Feeds were given as ad libitum to hens. Hens were subjected to heat stress for a period of 3 weeks after they reached 27 weeks of age. In the last two days of heat stress application, quality traits given below were determined on a total of 540 eggs, with 180 eggs from each group.

Egg weight: Weight of each egg was weighed by a scale with a sensitivity of $0.01 \mathrm{~g}$,

Shape Index: By means of shape index measurement instrument developed by Rauch,

Egg shell breaking strength: By means of shell measurement shell breaking strength instrument (Newton $/ \mathrm{cm}^{2}$ ),

Yolk Colour: In Roche scale value determined by digital yolk colour measurement instrument,

Shell Thickness: In mm, by means of micrometre,

Albumen height: Determined by tripod micrometre,

Haugh Unit: Calculated by the use of egg weight and albumen height,

Haugh Unit=100 $\log \left(\mathrm{H}+7.57-1.7 \mathrm{G}^{0,37}\right)$

$\mathrm{H}$ : Albumen height (mm)

G: Egg weight (g)

Statistical Analysis: The data obtained from the study were evaluated by using Minitab 16 Package Statistics Program. Analysis of variance was conducted with the intention of determining whether the differences between groups are essential, Tukey multiple comparison method was used in determining the differences between group means.

\section{Result and Discussion}

Egg quality traits in cold and heat stress conditions of the present study are presented in Table 2. No differences were found among different groups in terms of shape index, albumen height and Haugh unit of the egg quality traits in the study $(\mathrm{P}>0.05)$. However, shell breaking strength, egg weight, shell thickness and yolk colour 
differed among the temperature groups $(\mathrm{P}<0.05)$.

Egg shape index, Haugh unit and albumen height of the eggs did not change 3 weeks of heat or cold stress period in the present study (Table 2). These findings are not consistent with the results of Ahvar et al. (1982), Deaton (1983), Gill and Gangwar (1984), who found that albumen height and Haugh unit decrease when hens are kept under heat stress conditions. The difference between this study and other studies can be explained by the length of the stress period, which might not be long enough to observe the negative effects of the temperature stress especially high temperature $\left(32^{\circ} \mathrm{C}\right)$.

Table 1 Feed materials with chemical compositions fed to hens in the study

\begin{tabular}{|c|c|c|c|c|}
\hline Ingredients & 0-3 weeks & 4-10 weeks & 11-16 weeks & 17-30 weeks \\
\hline & \multicolumn{4}{|c|}{ Diet composition, $\%$ of the diet } \\
\hline Maize & 56.3 & 50.7 & 53.3 & 56.9 \\
\hline Soybean meal & 19.6 & 14.1 & 13.0 & 16.7 \\
\hline Sunflower meal & 10.0 & 10.0 & 5.1 & 8.0 \\
\hline Wheat middlings & 9.7 & 20.0 & - & - \\
\hline Full fat soybean & - & - & 16.0 & 4.0 \\
\hline Vegetable oil & 0.56 & 1.3 & 1.4 & 1.3 \\
\hline Other ingredients and additives & 3.8 & 3.9 & 11.2 & 13.1 \\
\hline Nutrients & \multicolumn{4}{|c|}{ Chemical composition } \\
\hline Dry matter, $\min (\%)$ & 88 & 88 & 88 & 88 \\
\hline Crude ash, $\max (\%)$ & 8 & 8 & 8 & 8 \\
\hline Crude protein, $\min (\%)$ & 19 & 18 & 16 & 18 \\
\hline Metabolic energy, $\min (\mathrm{kcal} / \mathrm{kg})$ & 2900 & 2800 & 2700 & 2800 \\
\hline Calcium, min-max $(\%)$ & $1-1.2$ & $1-1.1$ & $0.9-1$ & $3.5-4$ \\
\hline Available phosphorus min (\%) & 0.45 & 0.42 & 0.40 & 0.40 \\
\hline Lysine, $\min (\%)$ & 1.15 & 0.98 & 0.72 & 0.75 \\
\hline Methionin, $\min (\%)$ & 0.55 & 0.47 & 0.35 & 0.47 \\
\hline Methonin+cystein $\min (\%)$ & 0.85 & 0.76 & 0.58 & 0.78 \\
\hline Triptophan, $\min (\%)$ & 0.20 & 0.19 & 0.17 & 0.20 \\
\hline $\mathrm{NaCl}, \min -\max (\%)$ & $0.35-0.50$ & $0.35-0.50$ & $0.35-0.50$ & $0.35-0.50$ \\
\hline Crude cellulose, $\max (\%)$ & 4.5 & 5 & 6 & 6 \\
\hline Linoleic acid, $\min (\%)$ & 1.5 & 1.25 & 1.0 & 1.7 \\
\hline A vitamin $(I U / k g)$ & 13000 & 13000 & 10000 & 12000 \\
\hline $\mathrm{D}_{3}$ vitamin $(\mathrm{IU} / \mathrm{kg})$ & 3000 & 3000 & 2000 & 2500 \\
\hline E vitamin $(\mathrm{mg} / \mathrm{kg})$ & 20 & 20 & 20 & 20 \\
\hline $\mathrm{K}_{3} \operatorname{vitamin}(\mathrm{mg} / \mathrm{kg})$ & 2 & 2 & 2 & 2 \\
\hline $\mathrm{B}_{2}$ vitamin $(\mathrm{mg} / \mathrm{kg})$ & 5 & 5 & 5 & 5 \\
\hline $\mathrm{B}_{12} \operatorname{vitamin}(\mathrm{mg} / \mathrm{kg})$ & 0.02 & 0.02 & 0.01 & 0.01 \\
\hline Niacin $(\mathrm{mg} / \mathrm{kg})$ & 60 & 60 & 30 & 25 \\
\hline Mangan (mg/kg) & 100 & 100 & 100 & 60 \\
\hline Zinc (mg/kg) & 70 & 70 & 70 & 40 \\
\hline Iron (mg/kg) & 40 & 40 & 40 & 40 \\
\hline Cupper (mg/kg) & 7 & 7 & 7 & 7 \\
\hline Selenium (mg/kg) & 0.2 & 0.2 & 0.2 & 0.2 \\
\hline Cobalt $(\mathrm{mg} / \mathrm{kg})$ & 0.5 & 0.5 & 0.5 & 0.5 \\
\hline
\end{tabular}

Table 2 Egg quality traits

\begin{tabular}{l|ccc}
\hline \multirow{2}{*}{ Egg Quality Traits } & \multicolumn{3}{c}{ Groups } \\
\cline { 2 - 4 } & Control $\left(20 \pm 2^{\circ} \mathrm{C}\right)$ & Low $\left(12 \pm 2^{\circ} \mathrm{C}\right)$ & High $\left(32 \pm 2^{\circ} \mathrm{C}\right)$ \\
\hline Shape index & $78.244 \pm 0.181$ & $77.900 \pm 0.214$ & $77.278 \pm 0.850$ \\
Haugh Unit & $79.326 \pm 0.616$ & $80.852 \pm 0.590$ & $80.999 \pm 0.735$ \\
Albumen height $(\mathrm{mm})$ & $6.343 \pm 0.081$ & $6.508 \pm 0.079$ & $6.446 \pm 0.094$ \\
Shell breaking strength $\left(\mathrm{N} / \mathrm{cm}^{2}\right)$ & $43.372 \pm 0.596^{\mathrm{a}}$ & $44.856 \pm 0.497^{\mathrm{a}}$ & $41.584 \pm 0.534^{\mathrm{b}}$ \\
Shell Thickness (mm) & $0.337 \pm 0.002^{\mathrm{a}}$ & $0.335 \pm 0.002^{\mathrm{a}}$ & $0.323 \pm 0.002^{\mathrm{b}}$ \\
Egg Weight (g) & $59.990 \pm 0.330^{\mathrm{a}}$ & $59.874 \pm 0.307^{\mathrm{a}}$ & $58.226 \pm 0.311^{\mathrm{b}}$ \\
Yolk colour (Roche scale 12) & $11.278 \pm 0.050^{\mathrm{a}}$ & $11.400 \pm 0.069^{\mathrm{a}}$ & $10.804 \pm 0.078^{\mathrm{b}}$ \\
\hline Within colums,
\end{tabular}

Within columns, means followed by different letters are significantly different at $\mathrm{P}=0.05 ; \mathrm{n}=180 ; \pm$ expresses the standard error 
Shell breaking strength, shell thickness, egg weight and yolk colour did not differ in hens under cold stress condition but substantially decreased under heat stress condition. Lack of difference between hens in control group and hens in cold stress can be explained by the ability of hens to balance their body temperature by obtaining additional feed during cold environmental conditions. This probably does not cause a serious problem for the metabolic and productive activities of birds (Czaric and Fairchild, 2008). However a limitation in the provision of feed to the hens under cold environments may likely result in effects, which are similar to those observed in heat stress conditions. The findings of hens under heat stress are consisted with those of Ahvar et al. (1982), Deaton (1983), Gill and Ganwar (1984), Patterson (2004), Rozenboim et al. (2007), and Daniel and Bolnave (1979), but are in contradiction with the findings of Dai et al. (2009) that heat stress does not affect egg weight, shell thickness, shell breaking strength and yolk colour.

\section{Conclusion}

In conclusion, heat stress decreases egg quality traits in ATAK-S layers and this situation will have a negative effect on both producers and consumers. In order to prevent such losses, the construction and management of poultry houses for ATAK-S, especially in regions with warm climate should carefully be planned and anti-stress measures should be taken.

\section{Acknowledgements}

We would like to express our thanks to the Poultry Research Station Director and workers.

\section{References}

Ahvar F, Petersen J, Horst P, Thein H. 1982. Changes in egg quality during the first laying period at high .ambient temperatures. Archiv für Geflugelkunde, 46: 1-8.

Czarick M, III Fairchild BD. 2008. Poultry housing for hot climates. Poultry production in hot climates, edited by NJ Daghir, $2^{\text {nd }}$ ed.,ISBN-13:9781845932589, printed and bound in the UK by Cronwell Press, Trounbridge, Pp, 160.

Dai NV, Bessei W, Nasir Z. 2009. The effect of sodium chloride supplementation in the drinking water on water and feed intake and egg quality of laying hens under cyclic heat stress. Archiv für Geflugelkunde, 74: 217-226.
Daniel M, Bolnave D. 1979. The response of laying hens to heat stress. Proceeding, Third Australian Poultry and Stock Feed Convention, Suffers International, $23{ }^{\text {rd }}-28^{\text {th }}$ September, 178183.

Deaton JW. 1983. Alleviation of heat stress for avian egg production. World's Poultry Science Journal, 39: 210-217.

Durmus I, Sarica M, Aktan S, Yildiz T, Kahraman Z, Ertas S. 2009. Determination of production traits of newly developed local commercial layer hybrids. Poultry Research Journal, 8: 5-9.

Ehran MK, Bolukbasi SC. 2011. Effects of feeding diets supplemental with vitamin $\mathrm{E}$ and vitamin $\mathrm{C}$ on performance, egg quality and stereological and structural analysis of liver of laying hens exposed to heat stress. Italian Journal of Animal Science, 10: e58.

Feizi A, Shahazi M, Taifebagerlu J, Haghigat A. 2012. Effect of heat stress (HS) on production of Hy-Line layers. Research Journal of Biological Sciences, 7: 206-208.

Felver-Gant JN, Mack LA, Dennis RL, Eicher SD, Cheng HW. 2012. Genetic variation alter physiological responses following heat stress in 2 strain of laying hens. Poultry Science, 91: 1542-1551.

Gill SPS, Gangwar PC. 1984. Effect of heat stress on egg production and egg quality. Indian Journal of Animal Sciences, 54: 473-478.

Hui L, Feijiang T, Tao S, Xiaoting Z, Bin Z. 2010. Effects and mechanism of y-aminobutyric acid on laying performance and egg quality of laying hens under high temperature in summer. Chinese journal of Animal Nutrition, 22: 17451751.

Moshaly MM, Handricks GL, Kalama MA, Gehad AE, Abbas AO, Peterson PH. 2004. Effect heat stress on production parameters and immune responses of commercial laying hens. Poultry Science, 83: 889-894

Rozenboim I, Gal-Garber O, Proudman JA, Uni Z. 2007. The effect of heat stress on ovarian function of laying hens. Poultry Science, 86: 1760-1765.

Ryu MS, Cho KH, Shin WJ, Ryu KS. 2002. Influence of dietary supplemental betaine on performance and egg quality of laying hens during the heat stress. Korean Journal of Poultry Science, 29: 117-123.

Yardibi H, Turkay G. 2008. The effects of vitamin E on the antioxidant system, egg production and egg quality in heat stressed laying hens. Turkish Journal of Veterinary \& Animal Science, 32: 319-325.

ZiaoTing Z, YouMing W. 2002. Effect of aspirin on performance of laying hen and egg quality under heat stress. Journal of Zhejiang University, Agriculture and Life Science, 28: 298-302. 